\title{
Tran boundary Pool of the Irtysh River: Problems' Solutions of Municipal Facilities and Urban Development
}

\author{
Yuriy Vinokurov ${ }^{1, *}$ and Bella Krasnoyarova ${ }^{1}$ \\ ${ }^{1}$ Institute for Water and Environmental Problems, SB RAS, Molodezhnaya str. 1, Barnaul, 656038, \\ Russia
}

\begin{abstract}
The relevance of the study, due to the water difficult environmental situation increasing in the transboundary river basin (TRB) of Irtysh is related to the failure to address the issues of coordinated water use in the certain national segments: the Irtysh basin and its large left tributaries, the rivers Ishim and Tobol within the borders of Kazakhstan, China and Russia. The purpose of the study is to assess current processes of the water management system in the TRB formation and functioning, to identify current and potential problems of water use and to find ways to eliminate neutralize and prevent them in the future. The leading methods of research are system-dialectical, which provides for the water management systems study of the basin in question at the stage of formation, functioning and future development; as well as a comparative geographic method aimed at identifying and analyzing individual water management systems of the Irtysh TRB. Results of the study: The main water management problems in the Irtysh TBD were identified, their evaluation was determined and the their manifestation features in each of the identified national natural and economic subsystems were determined, the directions of their coordinated decision by all basin countries based on the methodology of strategic management adopted and widely implemented by the international scientific community. The significance of the study showed the severity of water management problems and the asymmetry of their solutions in different national segments of the Irtysh TRB, mainly due to incompleteness of the institutional environment for water resources management and inconsistency of the countries interests within its borders.
\end{abstract}

\section{Introduction}

The $\mathrm{Ob}$ River is one of the largest rivers in the world. It enters, together with its largest tributary of the Irtysh River, in the top 10 rivers of the world, both along the watercourse length and the catchment area, yielding to other major rivers in terms of water content, the flow of water in the estuary, the average annual and maximum observed one. On the territory of the basin there are 10 subjects of the Ural and Siberian federal districts of the Russian Federation, 6 oblasts / akimats of the Republic of Kazakhstan and the Altai district of the Ili-Kazakh region of the Xinjiang Uygur region of the $\mathrm{RCh}$. These regions are linked by a single water and economic system. They are in a state of constant coordination of their

* Corresponding author: bella@iwep.ru 
water management, environmental, economic and socio-cultural interests; not only at the international level between Kazakhstan, China and Russia (within one country), but also interregional levels, with interests of different countries, regions, industries, but also ethnic groups living within the same river different life support systems and institutional forms of water management.

We will focus on water problems use in the basin of the river Irtysh in this paper. Irtysh is the largest left tributary of the $\mathrm{Ob}$ River and belongs to transboundary river basins. Crossing part of the Chinese and Kazakh Altai named Kara (Black) - Irtysh, flows into Lake Zaysan in the Republic of Kazakhstan territory (RK). Irtysh or Ertis, as it is called in Kazakhstan, flows from this lake crosses the eastern territories of Kazakhstan, the Omsk and Tyumen regions of the Russian Federation, and in the region of Khanty-Mansiysk into Ob. According to the administrative positions, the Irtysh basin covers to some extent territories of the Omsk, Tyumen, Kurgan, Chelyabinsk, Novosibirsk, Sverdlovsk regions, the Khanty-Mansiysk Autonomous Okrug, and even Perm and the Republic of Bashkortostan; East Kazakhstan and Pavlodar, North Kazakhstan, Kostanay, Karaganda, Akmola regions (akimats) of Kazakhstan, Altai region of Xinjiang Uygur autonomous region of China and Bayan-Ulgiy aimak of Mongolia. About 15.0 million people live in the basin and in the zone of its influence, incuding about 9.0 million in the Russian regions and almost 5.0 million in Kazakhstan. In the Altai District of the XUAR, according to the given information, about 700 thousand inhabitants live, and the functioning of the Irtysh-Karamai channel allows the inclusion of the Irtysh river water resources in the water supply system still at least 500 thousand inhabitants of the Karamay city. The territory of Mongolia is practically uninhabited and is used only for seasonal pastures.

From the economic point of view, the Irtysh water resources and its tributaries are especially important for Kazakhstan, since they provide vital activity for almost $30 \%$ of its population and economy (29.5\% and $29.8 \%$, respectively), about $45 \%$ of the country's agricultural output . For the Russian Federation, the basin role, of course, is not so significant, according to the given size of the country, but it is unequivocally significant. About $9 \%$ of Russia's population lives on its territory and almost $12 \%$ of its gross regional product is produced, about 180.5 billion US dollars. The role of the Irtysh (or Kara-Irtysh) water resources is also very significant for China, given the low water availability of its population and the economy in general, and its western regions in particular.

Transboundary nature has not only Irtysh, but also Tobol and Ishim, its large left tributaries. Based on the formation nature and territorial division in the basin, we have identified seven national water use segments, including the Irtysh basin, there are three national segments within the borders of China, Kazakhstan and Russia; and two national segments in the Tobol and Ishim basins in the state borders of Kazakhstan and Russia. As a working hypothesis, the paradigm of asymmetric management water systems development was proposed in the framework of the above-mentioned national segments and a set of problems existence with different severity of their manifestation. The purpose of the study is to assess the formation current processes and water management systems functioning in the transboundary basin of the Irtysh River; the identification of actual and potential water use problems and the search for ways to neutralize, eliminate and prevent them in the future. In the process of this goal achieving, the following tasks were accomplished: the study of formation and functioning specifics of national water management in the Irtysh TRB; identification of water use problems in each national segments of the basin, covering primarily water scarcity and quality; assessment of the institutional environment for water resources management in individual countries, harmonization of their own interests with the rules of international water use in transboundary river basins and between the countries participating in the cooperation in the Irtysh TBD; expert assessment of the need and 
sufficiency of the measures proposed in different countries of the basin to solve their own water management problems.

The issues of water use in transboundary river basins are widely discussed by specialists of different branches. In the natural sciences field, the formation and hydrological regime processes of international water bodies and their variability are studied in relation to the water availability of the year, seasonality, various climatic and socio-economic factors. Social science, the legal basis for international and interregional cooperation, mechanisms for economically effective and environmentally sound management of water resources and water use are in the field of the interests [2]. A wide range of cross-border cooperation issues in the Irtysh TBD was considered at the scientific and practical conference "Water Resources of Central Asia and Their Use", held in Almaty in 2016, devoted to summarizing the decade declared results by the United Nations "Water for Life" [1, 3]. The Eurasian legal journal devoted to economic and legal issues of international cooperation in the Eurasian region is fully dedicated, since 2009. Each issue of the magazine contains special publications in the field of ecology and nature management. Particular attention is paid to the problems of water use in the Central Asia countries and the possibilities for their institutional solution.

\section{Materials and Methods}

The methodological basis of the study was the combination of two methodological approaches: system-dialectical and strategic management, implemented through a system of general scientific and geographical methods. Thus, the mechanism of the system-dialectical methodology provides for considering the system as "a set of ideas about its structure, functioning and development", as well as the state of functioning is supplemented by a change assessment in the internal content of the structure and the feasibility and significance of certain internal and external changes (Rjashko, 1995; Krasnojarova, 2004).

Algorithm of strategic management is widely accepted in international management practice, and in water use is realized through the system of integrated water resources management. It presupposes a diagnostic analysis of the water use state, the analysis of the problems and the environment of water body functioning, the formation and evaluation of scenarios for the water use development, targeted integrated programs, plans and specific activities for the selected scenarios implementation (Vinokurov \& Krasnojarova, 2016). In the process of research, statistical information, stock materials of the IWEP SB RAS, published results of other studies, media materials, own results in the field research were used [2].

\section{Results}

Features of the water management systems formation identified at the national segments of the Irtysh river transboundary basin were identified in the process of investigation.

Within the People's Republic of China boundaries (Kara-Irtysh Water Management System) are the sources of the Irtysh River (Kara-Irtysh or the Black Irtysh) $[4,5,6]$. KaraIrtysh provides the population needs, industry, agriculture, energy and tourism of the Xinjiang Uygur Autonomous Region (XUAR). Currently, the periphery is actively developing from Central China positions, the operation of the Black Irtysh-KaramayUrumqi canal system was launched, designed to provide the Karamai oil producing enterprises and the development of irrigation in the north-western regions.

The average annual volume of the Kara-Irtysh river flow is changing quite strongly and depends on the degree of water consumption in the China territory and natural and climatic 
conditions in the territory of its catchment area. According to the RSE "Kazhydromet" branch for the EKO for the last ten years (2006-2015), the minimum annual mean flow volume of the Kara-Irtysh river was observed in 2012 and amounted to $4.74 \mathrm{~km} 3$, the maximum in 2013 was $11.5 \mathrm{~km} 3$ with an average annual value of $7.2 \mathrm{~km} 3$, which was previously defined as $9.6 \mathrm{~km} 3$ (Aubakirov \& Evseeva, 2016). At present, about 1.5-2.0 km3 / year of the water are taken through the Black Irtysh-Karamai channel. In the long term, it is planned to seize water resources for different sources from 4.0 to $6.0 \mathrm{~km} 3 /$ year; the most value is $4.5 \mathrm{~km} 3$ / year, and this is almost $50 \%$ of the annual flow. Fluctuations and withdrawal of such runoff adversely amounts affect the hydrological state of Lake Zaisan, its inflow and biological productivity are significantly reduced. Although the quality of Kara-Irtysh River water resources on the border with Kazakhstan (HMS Buran) is characterized as a "clean" water body. On the Republic of Kazakhstan territory, Irtysh (with tributaries) is one of the main sources of water supply, providing the significant part of the population and the economy water needs of the Republic eastern and northern regions, as well as its capital, Astana. It should be noted that the basin principle of natural-economic division was adopted on the territory of the Kazakhstan Republic. Out of the eight basin natural-economic systems (BNES), three belong to the Irtysh river basin. This Irtysh (Ertis), Ishim (Esil) and Tobol-Togai (Tobyl-Togai) BNES, along with the Tobol river includes the basin of the Torgay inland river. Out of these three basins, the Irtysh state BNES is estimated as slightly transformed, the Tobol-Torgai is as a moderately transformed, and only Ishim is as a territory with significant anthropogenically transformed river runoff.

The basis of the Irtysh river water management system is the main watercourse with tributaries (except for the Tobol and Ishim rivers basins), its runoff is regulated by reservoirs of long-term and seasonal regulation. The largest of them Bukhtarma (project volume $49.6 \mathrm{~km} 3)$, Ust-Kamenogorsk $(0.66 \mathrm{~km} 3)$ and Shulbinskoye $(2.39 \mathrm{~km} 3)$ are located on the Irtysh river and represent a cascade of reservoirs (Elzhasov, 2012). Nowadays, the Irtysh River actually functions in the regime of a hydraulic structure from the upper tail of the Bukhtarma reservoir to the lower tail of the Shulba Reservoir [7,8,9].

The Irtysh cascade of hydroelectric power stations annually produces more than $80 \%$ of the entire hydropower of the Kazakhstan Republic. The existing reservoirs also perform a water-regulating function, removing sharp peaks of torrential floods in the spring-summer period and increasing the water flow to generate electricity in winter. At the same time, the Pavlodar region agriculture are suffered, where the richest hayfields were located on the territory of the previously flooded floodplain, as well as fisheries and shipping, all of them have practically lost their significance.

In addition, many small reservoirs of various functional purposes were created on the right tributaries of the main Irtysh. The cascade of small Leninogorsk hydroelectric power stations as part of the GOELRO program, and the previously existing Turgusunskaya hydro power plant, currently under construction, and others were built[]11. Hydraulic engineering structures of the Irtysh hydroelectric power stations are characterized by a high level of material and moral deterioration. The situation is aggravated by the regime of their exploitation, the ownership forms change and the repeated transfer of GTS part to an urgent concession, which took place in the post-1990s [12,13].

Currently, the regulation of the HPPs Irtysh cascade is largely carried out by the state, which is the Bukhtarma HPP owner at the entrance to the system, determines the water supply mode to the following Ust-Kamenogorsk and Shulbinskaya HPPs stages, jointly with Ust-Kamenogorsk and Sogrinskaya CHPs, transferred to the concession of AES Corporation. All these energy companies are located in the East Kazakhstan region and daily agree on the regimes

Further from Shulbinsky reservoir of the Irtysh river flows in a free regime practically up to Pavlodar, and then along the Irtysh-Karaganda offal canal part of $70 \mathrm{~m} 3 / \mathrm{s}$ flow. It is 
diverted to the central part of Kazakhstan for water supply to Astana growing needs, Karaganda industrial production and Northern Kazakhstan agriculture. At the same time, it is necessary to take into account the growing demand for water resources of metallurgical industries and electric power industry of the Pavlodar region and nuclear power plant's possible construction in Kurchatov works.

Characteristic substances concentrations periodically exceed the MPC in the water bodies of the Irtysh river basin are organic substances, oil products, phenols, ammonium nitrogen, compounds of iron, copper, zinc, manganese.

Water management system of the Ishim river transboundary basin is oriented to the water supply of Astana, Petropavlovsk and other cities of Northern Kazakhstan, as well as of its central regions agricultural water supply. The Ishim River water resources are formed mainly within Kazakhstan, and more than $65 \%$ of its runoff was spent on Russian territory (Tyumen south region) before the 1990s. At present the structure of the water allocation was changed somewhat. Previously run-off regulated by a number of reservoirs (more than 50 facilities of different capacity and filling mode) was now proved inadequate, either for water supply purposes or for the removal of the spring flood peak. The largest reservoir in Astana (Vyacheslavskoe) with a useful 375.4 million $\mathrm{m} 3$ volume, which was the main source of Astana water supply, does not cover the growing needs of the city. And in 2001, in order to replenish the Astana reservoir, facilities were commissioned for the water transfer from the Canal named after K.I. Satpaev to the upper reaches of the Ishim River with 288 capacity thousand $\mathrm{m} 3$ per day (Veshkurceva, 2010).

As a result, the water abstraction amount and pollution of the basin water bodies increased, some of them have a water pollution index "moderately polluted" and "contaminated", even the Nura-Ishim channel waters built for the purposes of Astana water supply are characterized as contaminated. The main pollutants in the Ishim River basin are manganese and copper.

Tobol is a twice transboundary river, its runoff is formed on Russian territory and enters Kazakhstan, returning to Russia, taking about $0.8 \mathrm{~km} 3$ / year of water from Kazakhstan territory. Within Kazakhstan, the Tobol is regulated by seven reservoirs with a total volume of $1.46 \mathrm{~km} 3$, only the largest Verkhnetobolsk (816.6 million m3) and Karatomar (586.0 million $\mathrm{m} 3$ ) are perennial and the rest are seasonal. A feature of the water management system functioning of the Tobol river basin in the borders of Kazakhstan is a highly regulated runoff with a high level of water resources seizure in order to meet the needs of mining and processing plants, cities and towns with a high level of GTS depreciation, built in the second half of the twentieth century $[14,15,16]$.

The Tobol River water quality in and the reservoirs in its basin is characterized mainly as moderately polluted, exceeding the MAC for copper, nitrogen nitrite (Omskie "frontoviki" predlagajut, 2016).

Three major water management systems of the actual river can be identified on the Russian segment of the Irtysh river transboundary basin from the border with Kazakhstan and to the mouths of Khanty-Mansiysk, Tobol and Ishim rivers. Each of them has its own set of problems and specific tasks that need to be addressed.

The water system of the Irtysh River is actually the Irtysh river itself, its right Om, Tara tributaries and other smaller watercourses, a number of hydrosystems, dams, etc., They are located mainly in the Omsk and Tyumen regions; which main purpose is flow regulation for water supply and irrigation. At the same time, the capacity of the existing reservoirs is clearly not enough to ensure uninterrupted water supply in Omsk, increase the average annual water level and improve the ecological and sanitary condition of the Irtysh River around the city. There were several project proposals to solve the city-millionaire Omsk water supply problems. One of them is connected with the construction of a dam and the reservoir creation, which will accumulate water in winter, and then evenly feed the Irtysh to 
the required natural and economic parameters. Out of the 14 variants of the hydro system location, the target was chosen at $1813 \mathrm{~km}$ of the watercourse in the Krasnaya Gorka area. The need for the construction of a hydroelectric complex was noted in the Water Strategy of the Russian Federation (up to 2025). The facility is included in the federal target program for the development of Russian water management complex; the project cost was 9.1 billion rubles in the of $2010 \mathrm{y}$. prices, on the terms of - $60 \%$ co-financing from the federal and $40 \%$ from the regional budget (Vremjaregionov, 2016). As an alternative reason, it was proposed to create a series of underwater artificial thresholds, which will provide a rise in level by reducing the river speed (Kostarev, 2014). There was one more suggestion based on the fact that the Irtysh level of water is even more affected by the extraction of sand, as the river bed is straightened, deepens and the water flows faster. To solve the water deficit problem, it would be sufficient simply to strengthen control in this area, up to the complete prohibition of sand extraction in arid years [SergejPrudnikov, 2014; Omskie "frontoviki" nastaivajut, 2016) [17,18].

However, despite of the proposed alternatives, a decision was made and in 2011 to build the Krasnogorsk water-lifting hydrosystem on the Irtysh with a channel water reservoir creation, which was supposed to solve the water supply issues to the Omsk population and economy and to remove peaks of water deficit in low-water periods (Fig. 1). According to the project, the construction completion date was 2014 y., but now the hydroelectric complex is ready for no more than $30 \%$, and the question arises about the expediency of its further construction, not all risks are taken into account (ErsynKudijarov, 2017).

The most problematic part in the Russian Irtysh basin is the Tobol river water system. There are such large industrial centers as Ekaterinburg, Chelyabinsk, Nizhny Tagil cities, etc with a high level of water consumption and sanitation on the banks of its $r$. Iset and $r$. Miass tributaries. In some parts of the basin (rivers Tagil, Miass), the withdrawing water resources share reaches $50-70 \%$ of the runoff volume and causes serious problems and fears for the leadership of the Sverdlovsk and Chelyabinsk regions' local population. In order to solve the problems of basin water supply, more than 600 reservoirs of different capacity were created. They are characterized by long-term operation. There are reservoirs built in the 17th-19th centuries in the basin, the oldest Nevyanskoye and Alapaevskoe were built in 1696-1700.

Many reservoirs are used as sources of drinking and industrial water supply, as well as for recreational purposes. There are water chillers and water storage facilities of HWPS power plants and small HPPs, which generate electricity for industrial enterprises and the population. Now it is planned to build additional small hydroelectric power stations on already existing dams for various purposes, as well as to increase the water availability of large cities and industrial units located in the basin, new intra-basin and inter-basin redistributions of the river Tobol, Ural and Kama rivers flow.

The Ishim River pool is the least loaded part of the Irtysh basin in the Russian Federation. Its water management system is represented by the Ishim River itself, which is the source of water supply to the population and economy of the Ishim and Ust-Ishim city district, and 6 small water reservoirs, which main purpose is to regulate the flow and accumulate water resources for irrigation and household consumption of the basin population. The main problems in the basin are associated with high water level differences in the river, as well as with the withdrawal of water resources in Kazakhstan, which has increased significantly in recent years with the country's capital transfer to Astana. High spring floods in 2016-2017 demonstrate its growing danger in the estuary of Ishim, when the water level reached its observable maximum for two consecutive years, up to 966 and 978 sm. in 2016 and 2017, respectively. The reasons for these floods are different, and the result is one, the flooding of Ishim whole districts, gardening partnerships, etc. (NovostiIshima, 2017). And these events 
require detailed analysis and timely decision, as the construction of the dam, carried out in 2016. It did not protect the neighborhoods of the city.

Characteristic substances, which concentrations are stable or periodically exceed the MPC in water bodies of the Irtysh river basin are organic substances, oil products, phenols, ammonium nitrogen, compounds of iron, copper, zinc, manganese. And the situation with an increased content of metals is typical for both Tobol and Irtysh; the excess of fish and water management MPCs is recorded both at the Russia and Kazakhstan border, and at the mouths of these rivers. In recent years, there is a reduction in the pollutants discharge into water bodies, but the content of iron, copper, zinc, manganese compounds remains overstated $[19,20]$

A brief analysis of the formation and functioning of the water management systems' national segments in the Irtysh river basin showed that each segment characterizes its own set of problems, which are mainly associated with uneven flow formation and irrational use and can be summarized as follows:

- depletion of water resources as a result of water fences increased in China and Kazakhstan, losses due to the evaporation from the Verkhne-Irtysh reservoirs hydroelectric power station cascade and other hydraulic structures;

- high level of water resources pollution in the River basin with heavy metals and oil products functioning in the upper Irtysh by the mining enterprises, metallurgical complex and heat power engineering;

- radiation contamination of the territory as a result of the Semipalatinsk test site action, the Lobnor test site in the RCh, the Mayak and others, we did not mention it above, but it does exist and is manifested both in the territory of the Republic of Kazakhstan and the Russian Federation;

- high regulation of river flow;

- emergency condition of hydraulic structures (GTS);

- lack of legal mechanisms for regulating water use in transboundary states.

Without dwelling in their description detail, let's name only the most important, in our opinion, features of their manifestation.

One of the main problems in the basin is water scarcity, including due to the fact that the upper and middle parts of the basin are confined to the arid areas of China and Kazakhstan, and the average annual river flow from Semipalatinsk to Omsk does not increase downstream of the river, but decreases by a 4- $5 \%$. The situation is aggravated by a high and increasing industrial load in the basin. The Irtysh River and its tributaries within Kazakhstan and China are the main waterway and source of water supply for the population and economy of these territories. At the same time, it should be noted, the absence of strictly agreed terms and volumes of water intakes. Lying upstream states and regions increase the volume of water intakes without taking into account the interests of the underlying water users $[21,22]$.

The next important systemic problem is the chemical and radioactive contamination of water bodies and transport pollutants. The main volume of discharges belongs to the Kazakhstan enterprises (more than $85 \%$ ) and slightly less than $14 \%$ to Russian ones. But, the main part of the sewage falls on conditionally clean water discharged from the reservoirs in Kazakhstani enterprises, while almost $100 \%$ of the Russian enterprises effluents are contaminated and insufficiently purified [23]. The main pollutants in the Irtysh basin are the mining and metallurgical enterprises of Ust-Kamenogorsk, Zyryanovsk, Leninogorsk and other industrial facilities, as well as the city-millionaire Omsk, which total discharge is almost 3,000 million m3 per year (Jekologicheskieriski, 2013).

In the Ishim river basin the volume of wastewater discharge hardly reaches 100 million m3, which greater part (94\%) comes to the territory of Kazakhstan from the KaragandaTemirtau enterprises and industrial areas of Astana and Petropavlovsk. The quality of 
Ishim's water has not changed significantly in recent years and is characterized as follows. In the upper reaches of the Vyacheslav River and the reservoir in Kazakhstan, water is estimated as "clean". Downstream, after discharges by Astana and Petropavlovsk industrial enterprises, as well as the Karaganda-Temirtau industrial area, the sewage water enters the river through the Nura-Ishim canal (the water in the canal corresponds to grade 5 quality "dirty") - "moderately polluted". Within the Russian part of the basin, getting into the city sewers in Ishim, the water is characterized as "contaminated" and "dirty" (Informacionnyjbjulleten, 2010) [24, 25].

The Tobol River, which crosses the Russian-Kazakh border twice, is characterized as "moderately polluted" in the territory of the Chelyabinsk region (the main polluters are the Chelyabinsk industrial area, as well as Yuzhnouralsk, Plast, Karkaly and Troitsk; Troitsk is one third of the total water intake and one-tenth of the dump) (Proekt ..., 2009); water is "dirty" in the Kurgan region of the Russian Federation (Kompleksnyjdoklad ..., 20042008).

In addition to chemical contamination, the basin's territory experiences radiation as a result of the prolonged action of the Semipalatinsk test site, the Lobnor test site in the $\mathrm{PRCh}$, the Mayak in the Chelyabinsk region, and others.

A serious systemic problem of the transboundary basin is the river flow regulation in the territory of Kazakhstan by a large Verkhne-Irtysh reservoirs' cascade (Bukhtarminsky, UstKamenogorsk, Shulbinsky), as well as Vyacheslavsky, Ishimsky, Sergeevsky and Petropavlovsk reservoirs on Ishim. The lack of water supplying in the Ishim basin population and the economy is covered by the transfer of the Irtysh river flow into the Nura River on the Irtysh-Karaganda canal. The rivers of the Tobol basin (Iset, Miass, Neiva, Ayat, etc.) differ in the high regulation in the Chelyabinsk and Sverdlovsk regions runoff of the Russian Federation. High flow regulation of the Irtysh River and its tributaries make it possible to meet the needs of the population and the economy in the northeast of Kazakhstan, Tyumen, Kurgan areas and Omsk regions of the Russian Federation, but the growth of water intake in China can intensify the actual problems of filling the Upper Irtysh reservoirs. In addition, there is a high threat of hydrotechnical safety due to the high physical in the basin (the Leninogorsk cascade of small HPPs of the derivational type was created in 1920-1940), and the moral depreciation of large hydraulic structures (Bukhtarminsky, Ust-Kamenogorsk, Shulbinsky), repeatedly changed the owner without proper technical support. The probability of seismic events occurrence is quite high in the region $[26,27]$.

Among the important systemic problems in the transboundary basin of the Irtysh River should especially note the insufficient development of the institutional environment for the transboundary water resources management. The given problem is polystructural, and it should be considered a little bit wider, than only the positions of water use management. Firstly, the PRCh is not a subject of international relations in the field of transboundary water use, and has not yet signed the fundamental agreements in this area on the Convention on the Protection and Use of Transboundary Watercourses and International Lakes and the Convention on the Law of the Non-Navigational Uses of International Watercourses, and operates only within its own legislation, actively increasing the seizure of LAS Black Irtysh water for irrigation, industrial and drinking water supply. Secondly, cross-border cooperation in the Irtysh river basin is implemented on a bilateral basis: between the two participating countries, Kazakhstan-China and Kazakhstan-Russia, since China refuses to tripartite cooperation on this issue. The existing agreements between China and Kazakhstan do not concern specific volumes of water allocation. The basis for interstate cooperation in the field of water relations between Kazakhstan and China is the "Agreement on Cooperation in the Sphere of Use and Protection of Transboundary Rivers" of September 12, 2001 (Astana), as well as two intergovernmental agreements (February, 
June 2011) in quality control of Transboundary Rivers and in the field of environmental protection. They contain the obligations of two states on cooperation in the field of water quality, protection, monitoring and monitoring of transboundary rivers and other environmental objects; including norms on cooperation in the field of preventing and eliminating water pollution in transboundary rivers; Kazakhstan-China Commission for Cooperation in the Field of Environmental Protection was established, but on the issue of water withdrawal limits, the parties could not develop a unified position (International legal mechanisms for determining the legal status of the Irtysh River). Modern China within the framework of the Northwest Territories Strategy, bordering on Kazakhstan, already now largely regulates in the upper Irtysh flow, planning to bring the percentage of withdrawals to $40-50 \%$ of its runoff [28]. New perspectives are also opening up in the connection with the development of the Chinese strategic initiative "One belt, one way." This strategy is aimed at activating economic development processes of poor internal regions of China through the contracts with major state enterprises, both inside and outside the country, in the infrastructure, energy and production spheres. This project envisages the involvement the economy and infrastructure of countries and regions in these processes, which are located along this Silk Road of the 21st century. Realization of the project "One belt, one way", certainly, will entail also water consumption growth, both for expansion of manufacture, infrastructural projects realization and needs of the population. Upper part of the Irtysh river basin is also in the zone of the One-Belt, One-Way strategy interests and requires increased attention to the potential projects in this zone, including taking into account the already developed hydrological and hydrobiological situation, for example, in the Lake Zaisan basin.

The Kazakh-Russian water relations are regulated by the Agreement between the Government of the Republic of Kazakhstan and the Government of the Russian Federation on the joint use and protection of transboundary water bodies dated September 7, 2010. The Kazakhstan-Russian Commission on the joint use and transboundary water bodies protection, among whose functions is the organization and conduct of joint activities in the field of rational use and transboundary water establishment protection of drainage parameters in agreed border crossings of transboundary water bodies, ensuring their compliance, assessment of water allocation parameters based on jointly executed water management and economic calculations in case of changes in the water management situation in the basins of transboundary water bodies, consideration of water management measures at transboundary water bodies at territories of the Russian Federation or the Republic of Kazakhstan.

Within the framework of this commission, working groups were established for individual rivers basins (Rossijsko-KazahstanskajaKomissija, 2007). It should be noted that even in close cooperation with the above-mentioned commission and working groups in the Russian-Kazakh relations, not everything is as harmonized as one would like. For example, at present, the Kazakh side is actively considering projects for the Russian waters transfer without preliminary detailed discussions with the Russian Federation and its regions. These projects include previously developed ones, for example, Belokatunskaya HPP with the Tikhaya River transfer part (the basin of the Katun River) and more modern projects for the construction of the Trans-Kazakhstan Channel with four additional branches of Astana, Petropavlovsk, Kostanay and Aktobe

As a potential donor pool the Irtysh River is considered. In addition, for the purpose of preserving national importance Lake Balkhash, it is proposed to transfer the Irtysh river part in the direction of the Bukhtarma River to the Lake Balkhash (Abishevetal, 2016).

The implementation of these projects will greatly affect the water supply of the Omsk southern regions and the city of Omsk, exacerbating the already difficult water management situation in the city, experiencing a water shortage, especially in shallow years and periods. 
The construction of the Krasnogorodsky site, near Omsk, started in 2011 is still far from complete and will solve all the Omsk Irtysh region tasks, although there were proposals for less radical intervention in the hydrological regime of the river through the underwater artificial construction rapids and the limitation of sand extraction, and including complete prohibition in dry years. Problems of water supply in the transboundary basins of the Tobol and Irtysh rivers are also addressed through new creation and reconstruction of existing reservoirs or inter-basin river transfer. The issues of the lack effectiveness, coordinated economic and legal regulatory for water use from interethnic and interregional positions are unresolved. There are no agreed water allocation limits, which is especially important in shallow years and seasons; there are also no strictly coordinated schedules of transboundary waters releases, taking into account the safe functioning of existing hydraulic structures and water management systems; there is a lack or low technological discipline of water use at enterprises, the main consumers of water resources and in housing and communal services of large cities; large losses of water resources in open reservoirs and canals. The developed Model Water Code of the Commonwealth remained a "model", when each country operates within its own national legislation, without coordination with other states.

\section{Conclusion}

In conclusion, it should be noted that within the river basins interests of the three states collide, and they can be solved only at the supranational level by seeking consensus, harmonizing interests and introducing integrated management tools. The concept of integrated water resources management has become widely accepted in the transboundary water bodies' management. This concept has undergone some practical approbation in the countries of the post-Soviet space. And, in our opinion, is nothing more than the methodology of strategic management implementation in relation to the water and economic system, the which algorithm, with is widely used in the practice of managing economically developed countries and transnational corporations, based on the mission of this system, the state diagnosis and the forecasted development trends. In our case, we need a comprehensive and impartial assessment of all strategic documents for the regional basin systems development, harmonization of drinking and domestic water use trends, taking into account the potential of introducing new technologies.

In addition, the international cooperation issues in the field of transboundary basins require the creation and maintenance of an international integrated monitoring system covering the water resources formation, the functioning of hydraulic engineering systems and spatio-temporal regimes for their use, including the certification of hazardous industries and the hydrotechnical safety declaration. In the case of creating such a system, it is possible to ensure more rational use of water resources and the water bodies preservation, as well as to improve the safety of existing hydraulic structures functioning and the advance forecasts quality of various hydrological events, up to extreme ones.

Study of the formation and functioning processes of water management systems in the complex transboundary basin of the Irtysh River showed the problems with manifestation in individual sub-basins and national segments of a single natural system. The orientation, activity of different countries' national management institutions vary considerably. So China is leading completely independent water policy in the Upper Irtysh territory, planning to seize almost $50 \%$ of its sources of the Kara-Irtysh River. Kazakhstan regards the Irtysh water resources as the main source of water supply for its Eastern and Central regions, for maintaining the Lake Balkhash water balance, for restoring the fishery importance of Lake Zaisan, planning to use the $\mathrm{Ob}$ resources and its tributaries sources for this purpose. At the same time, one can not fail to note some passivity of Russian water management bodies, both in the issues of water supply to Omsk, and the population and 
economy of the Eastern Urals industrial centers. And if the Omsk water supply, in the first case, is the issue of coordination interests and actions with Kazakhstan and China, the second case, the most heavily loaded in the Russian side basin, Tobol is fully determined by the actions of its own water management bodies, their adequate assessment of the situation and search by reducing the volume of water resources seizure or their restoration reproduction.

\section{References}

1. B.V. Ryashko, On the development of system-dialectical methodology, "ERGO", Ekaterinburg, UIF Science, 2, 56-78 (1995)

2. B.A. Krasnoyarova, System-dialectical approach to the management of the steppe eco (geo) systems of Eurasia, Vestnik of the Altai Science, 4, 191-194 (2014)

3. Yu. I. Vinokurov, B.A. Krasnoyarova, Diagnostic analysis of the state, problems and prospects of water use in the transboundary basin of the Irtysh River. Water Management of Russia 4, 47-61 (2016)

4. B.S. Aubakirov, A.A. Evseeva, Influence of the hydrological regime of the transboundary Kara Ertis river on the reproduction of fish populations, "Water for Life", Almaty, 2, 23-31 (2016)

5. NPP should have been built not in Kazakhstan, but in Omsk // http: //bk55.ru/news/article/39273/ (reference date: 02.03.2017)

6. The construction of the Kazakh nuclear power plant is postponed for an indefinite term // URL: https://riss.ru/analitycs/27353/ 01/03/2016

7. A. Elzhasov, Deficiency of water resources for water supply in the city of Astana, Water management in Kazakhstan, 2 (40), 8-9 (2012)

8. T.M. Veshkurtseva, Transformation of the water regime of the Tobol and Ishim rivers under conditions of anthropogenic impact, Bulletin of the Tyumen State University,7, 130-137, (2010)

9. Information bulletin on the state of the environment, RSE "Kazgidromet", Department of Environmental Monitoring, 1 (123), 89 (2010)

10. Omsk "front-line soldiers" offer to conserve the Krasnogorsky waterworks for the time being. / URL: http://kvnews.ru/gazeta/2016/aprel/-13/82365

11. Time of regions. In the Omsk region, the largest reservoir in Siberia will be built. URL: http://www.regtime.ru/owa/rt/rt_lenta.html?a_id=16603\&c_id=49\&r_id=6055

12. S.V. Kostarev, How to help the Irtysh become full again. Expert opinion. URL: http://omsk.yabloko.ru/news/index.phtml?id=673

13. S. Prudnikov. Omsk will be strangled by the Hydrosystem? URL: http://superomsk.ru/news/7268-omsk_zadushat_gidrouzlom/? 11/02/2014

14. Omsk "front-line soldiers" insist on the uselessness of the Krasnogorsk hydrosystem URL: http://omsk.bezformata.ru/listnews/na-bespoleznosti-krasnogorskogogidrouzla/45368077 (reference date: August 22, 2013)

15. E. Kudiyarov, Irtysh River in the relations between Kazakhstan, China and Russia URL: http://russiancouncil.ru

16. News of Ishim URL: http://www.ishimf.ru/Description: http://www.ishimf.ru/Documentation B4\% D0\% BD\% D1\% 8F 2.html, (2017)

17. Ecological risks in the transboundary basin of the Irtysh Rive Izdat. SB RAS, Novosibirsk, 165, (2013) 
18. Information bulletin on the state of the environment, RSE "Kazgidromet", 1 (123), 89 (2010)

19. The draft scheme for the integrated use and protection of water bodies (SKIVO) Irtysh. "Sovintervod" ZAO PO, M, 200 (2009)

20. Comprehensive report on the state of the environment in the Chelyabinsk region in 2004-2008, Ministry of Radiation and Ecological Safety of the Chelyabinsk region, URL: http://mineco174.ru/ mediadoklad.shtml (2008)

21. Convention on the Protection and Use of Transboundary Watercourses and International Lakes. Helsinki, URL: //http://www.un.org/en/documents/decl_conv/conventions/watercourses_lakes.shtml

22. Convention on the Law of the Non-navigational Uses of International Watercourses, New York, URL: http://docs.cntd.ru/document/901856694 (1997)

23. P. Bologs, Aral number two. How does China turn Kazakhstan into a desert // URL: http://lenta.ru/articles/2013/01/23/irtysh (date of circulation: 25.03.2014)

24. The Russian-Kazakhstan Commission on the joint use and protection of transboundary water bodies. URL: http://www.unece.org/env/documents/ $\quad \ldots \quad 2 \quad$ / ECE.MP.WAT.WG.2.2007.15.e.pdf

25. I.M. Malkovsky, L.S. Toleubaeva, To the formation of water supply unified system of the Republic of Kazakhstan, Questions of geography and geoecology, Almaty, 2, 19-23 (2010)

26. Territorial redistribution of water resources of Kazakhstan: the possibility and expediency, Ed. I.M. Malkovsky, Almaty, 414 (2012)

27. I.A. Abishev, A.R. Medeu, I.M. Malkovsky, L.S. Toleubaeva, Water resources of Kazakhstan and their use, "Water for Life", Almaty,1, 9-19. 2016

28. Model Water Code for the states-participants of the Commonwealth of Independent States: URL: http://www.intcode.ru/doc.php?docid=39530 